\title{
RESEARCH CORRESPONDENCE
}

\section{HABENARLA ROXBURGHII R.BR. : A NEW ADDITION TO THE SRI LANKAN ORCHID FLORA}

\author{
SAMANTHA SURANJAN FERNANDO ${ }^{*}$ and SAMANTHA GUNASEKARA ${ }^{2}$ \\ 1 Post Graduate Institute of Science, University of Peradeniya, Peradeniya. \\ 2 Biodiversity Protection Unit, Sri Lanka Customs, P.O. Box 518 Bristol Street, Colombo 1.
}

(Accepted: 23 August 2005)

Key words: Habenaria, India, Orchidaceae, Sri Lanka.

Habenaria, one of the largest orchid genera in the world, includes 600 species $^{1}$. All Habenaria species are terrestrial herbs with tubers. During the growing season, the aerial parts comprising one or many thin leaves arise from the tuber. In Sri Lanka 10 Habenaria species have been recorded to date, with five of them endemic to the island. ${ }^{2}$ This paper documents a Habenaria species hitherto not recorded from Sri Lanka.

This new record was found growing in the lower altitudes of the intermediate zone in the Eastern and Uva provinces. Prior to its collection, the habitat and population size of the species in each field location was noted during three growing seasons.

Habenaria roxburghii R.Br., Prodr.: 312 (1810). Nicolson in Saldanha \& Nicolson, Fl. Hassan Distr. Karnataka: 834 (1976); Pradhan, Indi. Orc. Guid. Iden.1976; Seidenfaden in Mathew 1563, 1983; Sathish \& Manilal, Cat.of Indian Orc. 77, 1994; Sathish \& Manilal in Manilal \& Sathish Orc. Mem. Tribut. Gunn. Seidenf. 197, 2004.

Synonyms: Habenaria platyphylla (Willd.) Spreng., Syst. Veg. 3: 690 (1826); Wight, Icon. Pl. Ind. Orient. t. 1709,1851; Hook.f. Fl. Brit. India 6:140. 1890; C. Fischer, Fl. Madras 3: 1470 (1027) 1928; Santhapu \& Kapadia, Orch. Bombay 19. 1966; Matthew, Mat. Fl. Tamilnadu Carnatic 352.1981; Abrah.\& Vatsala, Introd. Orch. 229, 1981.

Orchis platyphyllos Willd., Sp. Pl. 4: 11 (1805). Orchis roxburghii Pers., Syn. Pl. 2: 503 (1807).
Gymnadenia plantaginea Lind1. in N. Wallich, Numer. List: 7053 (1832).

Terrestrial, tuberous plants with leaves lying on the ground. Tubers $3-4 \mathrm{~cm} \times 1.2-1.8 \mathrm{~cm}$, fleshy white coloured, young tuber sometimes attached to the mature one. Roots few, short, vermiform. Stem very short. Leaves 2 or 3 rarely $1,1.4-6.7 \mathrm{~cm} \times 1.2-6.2 \mathrm{~cm}$, orbicular, sub orbicular or elliptic; apex round or obtuse; fleshy, waxy, dark green; sometimes only mid vein is visible in live state, in dried material 5 - 10 parallel veins visible with many cross veins. Terminal raceme $25-35 \mathrm{~cm}$, arising from center of rosette leaves; $3-5$ sterile bracts $1.2-3.3 \mathrm{~cm}$ long; flower bearing portion $6-8 \mathrm{~cm}$; flowers $10-20$, pure white with end of spur light green, $1.8-2.2 \mathrm{~cm}$ across when spread out; floral bract $14.4-15.4 \mathrm{~mm} \times 2.3$ - $3 \mathrm{~mm}$, narrowly lanceolate, finely denticulate, 3 veined; lateral veins incomplete branching out. Dorsal sepal $7.5 \mathrm{~mm} \times 5.6 \mathrm{~mm}$, oblong, blunt, 3 veined, finely denticulate; lateral sepals $9.3-9.8 \mathrm{~mm} \times 5.9-6.3 \mathrm{~mm}$, obliquely and broadly ovate, deflexed, 3 veined; lateral veins branching from base, finely denticulate. Petals 6.2 - $6.4 \mathrm{~mm} \times 2.2-2.3 \mathrm{~mm}$, acute, oblanceolate, 1 veined, finely denticulate, forming a hood with the dorsal sepal. Lip $3.5 \mathrm{~mm} \times 8 \mathrm{~mm}, 3$ lobed; mid lobe twice as long as lateral lobes and decurved backward in live state; 2 lateral veins either side of central vein, the inner branching at the base and the inner joining with the central vein distally, finely denticulate; spur $40 \mathrm{~mm}$ - $46 \mathrm{~mm}$ long, cylindrical, laterally compressed. Mouth spiny with a large tooth in the middle of the lower side. Column short; rostellum minute, stigmatic processes elongate, incurved towards mouth of spur, base continuous with the lip. Anther laterals adnate to the column, 2-loculed pollinia in 2

" Corresponding author 


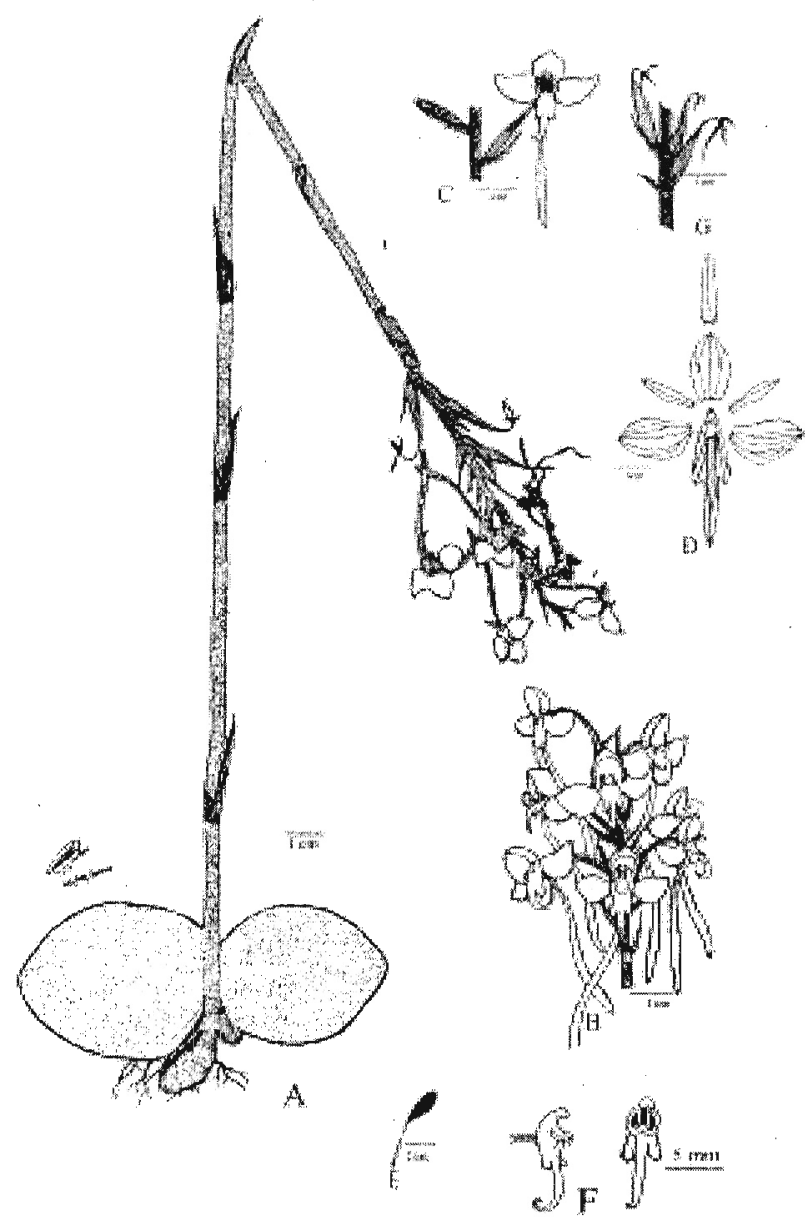

Figure 1: Habenaria roxburghii R.Br. showing the mature plant (A), part of the inflorescence (B), a single flower $(C)$, a bract, sepals, petals and lip spread out from the front (D), single pollinia (E), front and side view of column with lip (F) and young fruits (G).

masses, rhomboid; caudicles long; gland small. Ovary $1-1.5 \mathrm{~cm}$, pedicel twisted at base. Capsule $1-1.5 \mathrm{~cm}$ long, spindle shaped.

Specimens collected: Sri Lanka, Badulla District: Koslanda, Dec. 2001, S.S. 001, S.S. Fernando \& S. Gunasekara (PDA); Nikapotha, Nov. 2002, S.S. 002, S.S. Fernando (PDA); near $214 \mathrm{~km}$ marker on A4 road, Dec. 2002, S.S. 003, S.S. Fernando \& S. Gunasekara (PDA). Monaragala District: Bibile, Bulupitiya, Nov. 2003, S.S. 004, S.S. Fernando \& S. Gunasekara (PDA); Bibile, Bulupitiya, Nov. 2003, S.S. 005, S.S. Fernando \& S. Gunasekara (PDA).
Distribution: In Sri Lanka, the species is distributed in the south- eastern intermediate zone in open grasslands with a high intensity of sunlight and wet loamy soil. In India, Seidenfaden ${ }^{3}$ states its distribution as "plains in scrub jungles to $800 \mathrm{~m}$ on the hills, and on Balaghat, often sheltered inside thorny bushes or on the thin layer of soil by exposed rocks". It is also reported from the Southern Deccan ${ }^{3}$, Kudagu, Hassan, Tumkur, Karnataka, Kerala, Tamil $\mathrm{Nadu}^{4}$,Tinnelveiy District ${ }^{5}$, Travancore, Malabar, Andhra Pradesh and Madhya Pradesh. ${ }^{6}$

In Sri Lanka the orchid species $H$. barbata Wight in Wall., Peristylus cf. trimenii (Hook.f.) Abeywick. and Liparis nervosa (Thunb.) Lindley have been recorded in association with $H$. roxburghii.

Flowering has been recorded in Sri Lanka from November to January, but in India from JulySeptember. ${ }^{4,5}$

H. roxburghii is a new addition to the flora of Sri Lanka. Previously it was considered to be endemic to Peninsular India. ${ }^{5-7}$

The distribution of this species is very restricted and its habitat is highly disturbed by human activities such as anthropogenic fires, chena cultivation and new settlements. Conservation measures should be taken immediately to protect the habitat of this indigenous species.

\section{Acknowledgment}

We are grateful to the following: I. Samaraweera, R.W. Kumara, D.S Wickramasinghe and S. de Silva for assistance provided in the field; Dr. R. Ganeshan, of ATREE Bangalore, India for the supportive literature given to us; Dr. J. J. Wood of the Orchid Herbarium, Kew and Dr. C. Sathish Kumar in TBGRI in India who helped in verifying the identification of the species; Mr. P. Samarawikrama for illustrating the plant; Dr. S. Wijesundara of the National Botanic Gardens, Peradeniya for commenting on the manuscript; Profs. Nimal and Savithri Gunatilake at the University of Peradeniya for all their encouragement and guidance; Mrs. C. Seneviratne for proof reading the manuscript. 


\section{References}

1. Dressler R.L. (1993). Phylogeny and Classification of the Orchid Family. Cambridge University Press. pp. 143-144.

2. Jayaweera D.M.A. (1981). Orchidaceae. In: $A$ Revised Handbook to the Flora of Ceylon vol. II (Eds. M.D. Dassanayake \& F.R. Fosberg). pp. 344-365. Amerind, New Delhi.

3. Seidenfaden G. (1983). Orchidaceae. In: The flora of the Tamilnadu Carnatic, Part 3 Monocotyledons (Ed. K.M. Matthew). pp 15501611. The Ranipet Herbarium, St. Joseph's College, Tiruchirapalli, India.

4. Rao T.A. (1998), Conservation of Wild Orchids of Kodagu in the Western Ghats. The Karnataka Association for the Advancement of Science, Bangalore, India. pp. 242+XIII.
5. Abraham A. \& Vatsala P. (1981). Introduction to Orchids with Illustrations and Descriptions of 150 South Indian Orchids. Tropical Botanic Gardens and Research Institute, Trivandrum, India. pp. 229-231.

6. Sathish Kumar C. \& Manilal K. (2004). Orchids of Kerala. In: Orchids Memories: A tribute to Gunner Seidenfaden (Eds. K.S. Manilal \& C. Sathish Kumar). pp 197-198. Mantor Books and Indian Association for Angiosperm Taxonomy, India.

7. Sathish Kumar C. \& Manilal K.(1994). A Catalogue of Indian Orchids. pp. 76-77. Bishen Singh Mahendra Pal Singh, 23-A, New Connaught Place, Dehra Dun, India. 